\title{
DIREITO DE AÇÃO NO PROCESSO PENAL: POLÊMICAS E HORIZONTES POSSÍVEIS
}

\author{
RIGHT TO ACTION IN CRIMINAL PROCEDURE: CONTROVERSIES AND \\ POSSIBLE HORIZONS
}

\section{DERECHO DE ACCIÓN EN EL PROCESO PENAL: POLÉMICAS Y HORIZONTES POSIBLES}

\author{
AUGUSTO JOBIM DO AMARAL \\ http://orcid.org/0000-0003-0874-0583 / http://lattes.cnpq.br/4048832153516187 / guto_jobim@hotmail.com \\ Pontifícia Universidade Católica do Rio Grande do Sul \\ Porto Alegre, Rio Grande do Sul, Brasil. \\ RICARDO JACOBSEN GLOECKNER \\ http://orcid.org/0000-0002-1205-380X / http://lattes.cnpq.br/2085174043653648 / ricardogloeckner@hotmail.com \\ Pontifícia Universidade Católica do Rio Grande do Sul \\ Porto Alegre, Rio Grande do Sul, Brasil.
}

\section{RESUMO}

0 artigo trata de apresentar em linhas gerais, o desenvolvimento do conceito de direito de ação a partir do processo penal. Além de apresentar alguns problemas teóricos relativos ao direito de ação, o artigo trata de enfrentar problemas específicos da teoria eclética da ação, justificada pela sua posição predominante no Brasil, assim como a questão do objeto do processo, que deve necessariamente ser revista. Neste ponto, a renovação das categorias no processo penal é uma forma indispensável de se implementar a democracia, através da limitação do poder punitivo.

Palavras-chave: direito de ação; objeto do processo penal; teoria eclética da ação.

\section{ABSTRACT}

The article intends to present, in a general scheme, the development of the "right to action" concept from the criminal procedure perspective. Besides presenting some theoretical issues concerning the "right to action", the article deals with some specific problems of the "eclectic action theory", justified by its predominant position in Brazil, as well as the question of the object of criminal procedure, that must necessarily be reviewed. In this issue, the renewal of criminal procedure categories is an indispensable way to fulfill democracy, through the punitive power limitation.

Keywords: right to action; criminal procedure object; eclectic action theory.

\section{RESUMEN}

Este artículo intenta presentar, en un esquema general, el desarrollo del concepto de "derecho a la acción" desde la perspectiva procesual. Demás de presentar alguna cuestiones teoricas acerca del "derecho a la acción", el artículo trata de alguns problemas específicos de la "teoría eclética", justificada por su posición predominante en Brasil, así como la cuestión del objecto del proceso penal, que precisa ser necesariamente revisitado. En este punto, la renovación de las categorias procesuales penales é una forma indispensable para atingir la democracia, a través de la limitación del poder punitivo.

Palavras-chave: Derecho de acción; objeto del proceso penal; Teoría ecléctica de la acción. 


\section{SUMÁRIO}

INTRODUÇAO; 1 LINHAS GERAIS DA INDIFERENCI(AÇÃO) À AÇÃO COMO DIREITO AUTÔNOMO; 2 CONDIÇÕES DE POSSIBILIDADE PARA PENSAR A AÇÃO PENAL; 2.1 A Teoria Eclética da Ação; 2.20 Objeto do Processo Penal; CONCLUSÃO; REFERÊNCIAS.

\section{INTRODUÇÃO}

Dentro da trilogia estrutural da ciência do processo ${ }^{1}$ (jurisdição, ação e processo), por alguma lógica, podemos até ter inicialmente por preocupação o exame da ação (arranque), a seguir o do processo (recorrido), e depois a jurisdição (destino). De forma diversa, não obstante, conviria pedagógica e metodologicamente começar pela jurisdição, que é a razão de ser da ação, seguir depois por ela, que seria o motor do processo e, finalmente, terminar com este, que exige o exercício de uma e o funcionamento da outra.

Não obstante, por hora, os esforços, devem se dirigir para um caminho mais responsável cientificamente, sob qualquer dos três termos. Desde a expressão "trípode desvencijado", desde logo, deve-se ter a dimensão da instabilidade conceitual que há sobre estes três elementos, em virtude de nunca se ter atingido a plenitude conceitual convincente em razão da incerteza doutrinária e da falta de definitividade que pairam sobre o atual estado das investigações acerca de tais conceitos. ${ }^{2}$ Diretamente ao ponto de nossas preocupações - a expressão ação será utilizada em seu sentido estritamente processual, entendida como sinônimo de um poder jurídico de provocar a atuação do poder judiciário (quer dizer, um verdadeiro direito à jurisdição ${ }^{3}$ ) que cuida diretamente da relação entre ação e direito.

Para tanto, indagaremos quais os principais problemas envolvendo o direito de ação no processo penal, principalmente tendo em vista a consagração da chamada "teoria eclética" no Brasil. Parte-se metodologicamente da retomada profunda da formação dos institutos

\footnotetext{
1 PODETTI, José Ramiro. Trilogia estructural de la ciencia del proceso. Revista de Derecho Procesal. Año II. $1^{\text {a }}$ Parte. Buenos Aires: Ediar, 1944. p. 113-170; sem olvidar o clássico Teoría y técnica del proceso civil y trilogía estructural de la ciencia del proceso civil. Buenos Aires: Ediar, 1963.

2 "Jugando con los verbos ser y estar, podríamos afirmar que del proceso sabemos donde está, pero no lo es (si una relación o una situación jurídica, etc.); de la jurisdicción sabemos lo que es, pero no donde está (si en el derecho procesal o en el derecho constitucional (...)), y de la acción no sabemos ni lo que es (pugna entre las teorías abstractas y las concretas) ni donde está (si en el campo del derecho material o en el procesal)." ALCALÁ-ZAMORA Y CASTILLO, Niceto. Estudios de Teoría General e Historia del Proceso (1945-1972). Tomo I ( $n^{\circ}$ 1-11). México: Universidad Nacional Autônoma de México, 1992, p. 322-323 (cit. nota 11).

${ }^{3}$ COUTURE, Eduardo J.. Fundamentos do Direito Processual Civil. Tradução do Dr. Rubens Gomes de Souza. São Paulo: Saraiva, 1946. pp. 41 ss..
} 
processuais para alcançar as indevidas adaptações e incorporações realizadas no objeto do processo em matéria penal.

\section{LINHAS GERAIS DA INDIFERENCI(AÇÃO) À AÇÃO COMO DIREITO AUTÔNOMO}

Historicamente, antes de uma plena orientação publicística e autônoma da ação, havia uma doutrina civilista/privatista (na esteira dos pandectistas) que via a Ação como o direito em movimento, nada mais que sua possibilidade dinâmica, na velha forma do "direito armado de capacete e preparado para a guerra". Obviamente, assim, quando se trata de trafegar sobre o panorama doutrinário acerca da natureza jurídica da ação, mesmo que proclamada sua autonomia, tal desenho "é tão vasto, e as divergências tão acentuadas, que já se chegou a afirmar que a sua exposição seria caluniosa para a ciência processual”"

Entretanto, tratando-se de insistir sobre algumas linhas gerais de orientação, destinadas a simplificar a exposição, pode-se ver alguma terminologia atrelada ao menos em duas vertentes: as ditas doutrinas do direito concreto à tutela jurídica e as doutrinas do direito abstrato de agir (por um lado obrigacionistas, por outro, jurisdicionalistas ${ }^{5}$ ). De início, foi a discussão técnica entre Windscheid e Muther de 1856-7 sobre o conceito da ação romana do ponto de vista do direito moderno que deu ao último teórico condição de configurar a ação como um direito contra o Estado, direito público subjetivo que teria por pressupostos um direito privado e a sua violação ${ }^{6}$.

Adolph Wach, em seu “Da Ação Declaratória” (Der Feststellungsanspruch) de 1888 avança, sobretudo, em duas diretrizes: o caráter público e concreto da ação. Ou seja, se, por um lado, a ação é um direito no qual incumbe ao Estado uma parte fundamental, pois é ele que exerce a tutela jurídica, por outro viés, a concretude decorre da eficácia que a ação tem contra o adversário para que se submeta ao ato de proteção estatal (apenas havendo, assim, ação

\footnotetext{
${ }^{4}$ COUTURE, Eduardo J.. Fundamentos do Direito Processual Civil, p. 29.

${ }^{5}$ ALCALÁ-ZAMORA Y CASTILLO, Niceto. Estudios de Teoría General e Historia del Proceso (1945-1972). Tomo I. p. 335-337.

6 PUGLIESE, Giovanni. Introducción. In: Polémica sobre la Actio. WINDSCHEID, Bernhard; MUTHER, Theodor. Traducción del alemán por Tomás A. Banzhaf. Buenos Aires: EJEA, 1977, pp. XI-XLI. Ademais, sobre este ponto de vista, ver CAMARGO, Acir Bueno de. "Windscheid e o rompimento da fórmula de Celso" e KUHLMANN, Sylvio Roberto Degasperi. A actio sob a ótica de Muther, a partir da definição de Celso, ambas In: Crítica à Teoria Geral do Direito Processual Penal. COUTINHO, Jacinto Nelson de Miranda (Coord.). Rio de Janeiro: Renovar, 2001. p. 111-144 e pp. 145-167, respectivamente.
} 
quando a demanda é procedente). ${ }^{7}$ Em suma, trata-se de uma "pretensão à tutela jurídica" (pretensão dirigida no escopo de obter do Estado a satisfação do interesse à tutela jurídica segundo as fórmulas previstas no direito processual, além da pretensão, dirigida contra o adversário, de que se submeta à concessão da tutela jurídica - Rechtsschutzanspruch). Noutros termos, "direito a uma sentença favorável"8.

Ainda, pode-se ver como variante desta teoria, a ação compreendida como direito potestativo, elaborada a partir da prolusão de Giuseppe Chiovenda de 1903, “Azione nel Sistema dei Diritti". Partindo da autonomia da ação, todavia ele não aceita seu conceito (ainda que não o negue) rigorosamente publicístico, afastando-se de Wach em algum sentido. Como um direito também privado, a ação não seria exercida contra o Estado, mas apenas endereçada a ele. Segundo esta postura, a ação não seria um direito público, senão também um direito privado, porquanto o particular que propõe ação não exerce contra o Estado nenhum direito ao qual este se ache obrigado. Desta forma, a ação seria um direito potestativo por excelência (diferente dos direitos reais e pessoais) - instituto este que, à altura, Wach ignorava. Diante da ação, estaríamos frente, não a "direitos a uma prestação", mas a "direitos de formação" que originam, modificam ou extinguem direitos subjetivos pela vontade do titular. A relação com o Estado que se estabelece pela ação, diz Chiovenda, não é mais que um meio de obter certos efeitos contra o adversário, não sendo ela, portanto, o "poder jurídico de dar vida à condição para a atuação da vontade da lei. [...] A ação é um poder que nos assiste em face do adversário em relação a quem se produz o efeito jurídico da atuação da lei.". 9

Haveria, pois, nesta conjuntura, de se conseguir superar a explicação acerca da ação improcedente que emperrava o caráter concreto da ação e dar um fundamento único a ambas as formas de ação, quase que prescindindo do direito subjetivo material. Mais uma vez, o problema

\footnotetext{
7 WACH, Adolf. Manual de Derecho Procesal Civil. Buenos Aires, Ediciones Jurídicas Europa-América, 1977. pp. 25-26.

${ }^{8}$ COUTURE, Eduardo J.. Fundamentos do Direito Processual Civil, pp. 30-31.

9 Ressaltando a tradição latina de vislumbrar na ação especialmente a direção contra o adversário, em oposição à tradição germânica fixada antes na relação com Estado (veja-se, neste ponto, a Klagerecht, a qual Windscheid acentuou seu diferencial quanto a actio romana), escreve: “(...) a coação é inerente à ideia de direito (não no sentido de que, para se ter direito, se deve poder efetivamente atuá-lo, e sim no de que tende a atuar com tôdas as fôrças que estão de fato à sua disposição); se em verdade a vontade concreta da lei, quando o devedor deixa de satisfazê-la com sua pretensão, tende à sua atuação por outra via, e que, mesmo em numerosíssimos casos, há vontades concretas de lei cuja atuação só se concebe por obra dos órgãos públicos no processo; todavia, normalmente, êsses órgãos só a pedido de uma parte podem prover à atuação (nemo iudex sine actore), de modo que, normalmente, a atuação da lei depende de uma condição, a saber, da manifestação de vontade de um indivíduo; e diz-se que êsse indivíduo tem ação, querendo dizer-se que tem o poder jurídico de provocar, com seu pedido, a atuação da vontade da lei." CHIOVENDA, Giuseppe. Instituições de Direito Processual Civil. Volume I (As relações processuais, A relação processual ordinária de cognição). 3. ed. São Paulo: Saraiva, 1969, p. 24.
} 
da conexão ${ }^{10}$ do direito substantivo com o direito processual emergia como o mais radical deste ramo do direito ${ }^{11}$ : caminhava-se sobre o limite tênue entre não levar a cabo profundamente a distinção entre direito subjetivo à prestação e o direito subjetivo de ação, reduzindo-se o direito processual a uma "res mere facultatis".

Por seu turno, a doutrina que define a ação como "um direito abstrato de agir", basicamente, parte da premissa de que há um direito de agir em juízo independente do direito subjetivo válido. É o direito de expor pretensões, de que estas sejam ouvidas, e de que sejam eventualmente acolhidas. Respondendo à excessiva generalização que the acusavam, Degenkolb, um dos precursores deste viés, viu-se forçado a impor forte limitação a sua ideia, aduzindo de início que apenas pertence a ação a quem possa "sinceramente afirmar a existência de uma norma legal" exigindo "uma justa esperança de ter direito como garantia do valor jurídico da sua consciência". O que de fato em nada superava tal dificuldade crítica, admitindo, por fim, na ação não já um simples direito abstrato, mas uma capacidade jurídica de obter uma decisão favorável em juízo contra o adversário, rotundamente aderindo à formulação de Wach. ${ }^{12}$ Ainda assim, teve em Alfredo Rocco e Josef Kohler notáveis seguidores, aquele sustentando a bifurcação da ação em interesse primário (tutelado pelo direito) e secundário (interesse a tal tutela), e este tendo a ação como direito da personalidade. ${ }^{13}$

Enfim, segundo Tucci ${ }^{14}$, ao analisar as inúmeras objeções e críticas que receberam as proposições tradicionais sobre a ação, importa decantar que as vertentes imanentistas, como dito, não logravam explicar o fenômeno da ação infundada, isto é, a proclamação da inexistência de direito subjetivo material, bem como a existência da ação declaratória negativa. De outra parte, a teoria da ação como direito concreto (Wach) esbarra nos casos dos pedidos julgados improcedentes ${ }^{15}$. Já quanto à doutrina da ação como direito potestativo (Chiovenda), em que pese o Estado e o cidadão tenham interesse na atuação da lei, isto não significa que não tenham direitos e obrigações (deveres) recíprocos. Por fim, a visão da ação como "direito abstrato" peca pelo seu excessivo abstracionismo, em particular, identificando jurisdição com o

\footnotetext{
10 Neste sentido, por todos, CHIOVENDA, Giuseppe. Instituições de Direito Processual Civil, p. 21 e CARNELUTTI, Francesco. Lições sobre O Processo Penal. v. 2. Campinas: Bookseller, 2004, p. 21.

11 “(...) il problema del rapporto tra diritto sostanziale e processo, l'unico vero problema della teoria generale del diritto, dal quale tutti gli altri dipendono (...)" SATTA, Salvatore. Introduzione. In: Soliloqui e Colloqui di un Giurista. Prefazione di Fernando Mazzarella. Nuoro: Ilisso, 2004, p. 31.

${ }_{12}$ COUTURE, Eduardo J.. Fundamentos do Direito Processual Civil, p. 37.

${ }^{13}$ SERRA DOMíNGUEZ, Manuel. Jurisdicción, acción y proceso. Barcelona: Atelier, 2008, pp. 194-197.

${ }_{14}$ TUCCI, Rogério Lauria. Teoria do Direito Processual Penal: jurisdição, ação e processo penal (estudo sistemático). São Paulo: RT, 2002. p. 69-70.

${ }^{15}$ COUTURE, Eduardo J.. Fundamentos do Direito Processual Civil, pp. 24-25.
} 
juízo, esquecendo-se que o juízo estatal é simples meio para se atingir um fim que está para além dele e no qual verdadeiramente se explica a função jurisdicional.

\section{CONDIÇÕES DE POSSIBILIDADE PARA PENSAR A AÇÃO PENAL}

Antes mesmo de avançar, algumas considerações se fazem necessárias. Preliminarmente, em um processo do tipo inquisitório, o conceito de ação se torna completamente irrelevante. Este processo de "parte única", como queria Manzini ${ }^{16}$, dispensa a ação como conceito operativo, pois a ação requer a dialética processual que falta ao modelo inquisitório. Portanto, parece acertada a posição de Gómez Orbaneja e Herce Quemada quando advertem constituir a ação um objeto exclusivo do processo penal acusatório ${ }^{17}$. Evidentemente, o princípio nemo iudex sino actore não é aplicável ao regime inquisitório, ao menos como regra. Da necessidade da preservação da imparcialidade é que decorre o direito de ação ${ }^{18}$.

Um dos pontos convergentes sobre o conceito de ação situa-se no fato de que o seu excesso de teorização foi um dos responsáveis pela confusão conceitual, uma vez que a polissemia alcançada pelo termo “direito de ação" sobrecarregou o conceito. Este excesso permitiu concluir, em aguçada crítica de Fairén Guillén ${ }^{19}$, que o número de estudos sobre o direito de ação é relativo ao descontentamento proporcionado, sendo a crítica rainha absoluta. Pode-se afirmar, portanto, que existem inúmeros conceitos de ação que significam coisas completamente diversas ${ }^{20}$. Como vimos, em alguns momentos, por exemplo, corresponde a um direito, em outros a ação é apresentada como pretensão etc. ${ }^{21}$.

De forma a tentar sistematizar, Couture, afirma que existem três grandes acepções metodológicas do conceito de ação, que geram consequências completamente distintas: a) como sinônimo de direito, no sentido da expressão "o autor carece de ação"; b) como sinônimo de

16 "El proceso penal, como proceso propio de la justicia administrativa, es, si puede decirse así, un proceso de parte única (imputado), ya que el acusador sólo es parte en sentido formal (esto es, em cuanto se contrapone al imputado en la actividad procesal), siendo un órgano del Estado por su instituto imparcial, que hace valer sin duda una pretensión del Estado mismo, pero encaminhada a la actuación del derecho objetivo, por un interés público superior, y no de parte". MANZINI, Vincenzo. Tratado de Derecho Procesal Penal. t I. Buenos Aires: El Foro, 1996.

17 Cf. GÓmeZ ORBANEJA, Emilio; HeRCE QUEMADA, Vicente. Derecho Procesal Penal. 10. ed. Madrid: Artes Gráficas y Ediciones S.A, 1987.

${ }^{18}$ MORENO CATENA, Victor; CORTÉS DOMINGUEZ, Valentín; GIMENO SENDRA, Vicente. Introducción al Derecho Procesal. 3. ed. Madrid: Colex, 2000, p. 121.

${ }^{19}$ FAIRÉN GUILLÉN, Victor. Estudios de Derecho Procesal. Madrid: ERDP, 1964, p. 64.

${ }^{20}$ Cf. PEKELIS, Alessandro. Azione. In: Nuovo Digesto Italiano. v II. torino: UTET, 1938, p. 92.

21 SILVA, Ovídio Baptista da; GOMES, Fábio Luiz. Teoria Geral do Processo. 4. ed. São Paulo: Revista dos Tribunais, 2006, pp. 93-94. 
pretensão, no sentido mais usual empregado pela doutrina e textos legislativos. Este sentido foi empregado ao largo do século XIX e se mantém em vigência atualmente. Fala-se, portanto, em ação fundada e infundada, ações reais e pessoais etc. Nestes vocábulos, a ação seria a pretensão de que se tem um direito válido e em nome do qual se promove a demanda; c) como sinônimo da faculdade de provocar a jurisdição, utilizada por Couture ao largo de seu livro22. Portanto, para se avançar no estudo da ação e de sua inaplicabilidade ao processo penal, há que se desfazer fundamentalmente estes equívocos ${ }^{23}$.

Um texto de Calamandrei é suficiente para demonstrar a complexidade e a polissemia assumidas pelo conceito de ação. A partir de um texto publicado na Rivista di Diritto Processuale Civile, intitulado "La relatività del concetto di azione", Calamandrei foi tachado de relativista. Basicamente o adjetivo tomou por base algumas considerações do processualista italiano que sustentou estar o conceito de ação dependente do ordenamento jurídico e do contexto histórico.

Calamandrei inicia seu estudo diagnosticando que a intensa celeuma no que concerne às discussões referentes ao conceito de ação, movendo nesta empreitada a discussão sobre outros temas como jurisdição, natureza jurídica do processo etc., mesmo que impregnada de uma pretensão cientificista de interpretar cada texto ao pé da letra, não escapa de se colocar como um problema político ${ }^{24}$. Calamandrei sugere que a tentativa de lograr êxito na definição correta de ação é algo vão e frívolo. A própria definição de ação parte necessariamente da interpretação dada relativamente aos interesses individuais e públicos, que pressupõe, antes de tudo, uma orientação política que faça prevalecer um sobre o outro. De fato, como reconhece o próprio Calamandrei, a análise sobre a ação, especialmente desenvolvida pela ciência processual tedesca se revela, antes, como uma discussão sobre o Estado, tal como demonstrara Pekelis, "e que consequentemente, o ciclo das teorias sobre a ação seguiram a mesma cronologia da histórica política do século XX"25.

A crise da teoria da ação, para Calamandrei, tem como pressuposto a progressiva publicização do direito, com a consequente relativização e redimensionamento do conceito de

\footnotetext{
${ }^{22}$ COUTURE, Eduardo. Fundamentos del Derecho Procesal Civil. 4. ed. Montevideo: Be de F, 2005, p. 50.

${ }^{23}$ Cf LEAL, Rosemiro Pereira. Teoria Geral do Processo. 7. ed. Rio de Janeiro: Forense, 2008, p. 129.

24 "Le ricostruzioni della dogmatica sono dunque, in ogni caso, il resultato di un compromisso trai il diritto positivo e le premesse tendenziali a cui il giurista lo ricollega: ed è così, coll'evolversi di queste mobili premesse, che la dogmatica riesce a ringiovanire perenemente gli istituti giuridici, e ad adeguarli, anche se la lettera delle disposizioni rimane immutatam alla realtà sociale che sempre si rinova". CALAMANDREI, Piero. La Relatività del Concetto di Azione. Rivista di Diritto Processuale Civile. v. XVI. Parte I. Padova: CEDAM, 1939, p. 23.

${ }^{25}$ CALAMANDREI, Piero. La Relatività del Concetto di Azione, p. 24.
} 
direito subjetivo. Tais teorias são relativas umas às outras, não podendo ser nem absolutamente falsas nem tampouco absolutamente verdadeiras. Afirma que a ação, antes de ser uma construção teórica dos juristas é uma realidade prática de todos os Estados civilizados ${ }^{26}$. Contemporaneamente, temos um processo essencialmente de ação, isto é, um processo no qual o órgão judiciário não atua sobre a realidade social para conhecê-la ou para the modificá-la em seus aspectos jurídicos, mas para fazê-lo nos estritos limites da proposta apresentada pelo autor $^{27}$. Pode-se afirmar, portanto, que a teoria da ação se funda basicamente na proibição da autotutela ${ }^{28}$. Assim, a jurisdição pressupõe a ação, que será o seu limite e uma condição de seu funcionamento.

Calamandrei chama a atenção para o acerto da teoria de Wach, influenciada por Muther como vimos, que reconhece a existência de um direito endereçado ao Estado-juiz ${ }^{29}$. Todavia, será para Calamandrei fundamentalmente Chiovenda quem consegue trazer o almejado equilíbrio entre interesse individual e o público ao conceber a ação como uma espécie de direito potestativo ${ }^{30}$. Calamandrei conclui que todas as teorias da ação podem, apesar dos conflitos entre si, serem justificadas e corresponderem a um determinado momento histórico, em relação a sua complexidade ${ }^{31}$.

Além destes problemas, deve-se prestar atenção ao referido por Jardim, para quem "a teoria da ação deixou de ser o polo metodológico da ciência do processo, estando os estudiosos mais preocupados com o objeto do processo e a demanda, como categorias centrais de todo o sistema processual" 32 . Isto se reflete a partir da praticamente inexistente controvérsia no processo penal, de que no processo penal se aplica a “teoria eclética da ação". Para além, esta ausência de interesse na temática da ação se constitui como um reflexo da sistemática de Manzini e de toda a tradição inquisitorial que imanta o Código de Processo Penal Brasileiro. Aceitam-se, por óbvios, conceitos como legitimidade de parte, interesse jurídico, possibilidade jurídica do pedido, mediados por um esforço silogístico de enquadrar tais categorias em um dos

${ }^{26}$ CALAMANDREI, Piero. La Relatività del Concetto di Azione, p. 26.

27 CALAMANDREI, Piero. La Relatività del Concetto di Azione, p. 26.

28 "Una giurisdizione esercitata d'ufficio, alla quale l'organo giudicante procedesse di própria iniziativa, senza attendere la sollecitazione del soggetto agente, repugnerebbe al concetto che modernamente $c i$ siamo fatti della funzione del giudice, il quale, per conservarsi imparziale, deve attendere d'esser richiesto e limitarsi a render giustizia a chi la domanda: e se ci raccontassero che un magistrato, senza esser richiesto da alcuno, si è messo in viaggio alla scoperta dei torti da raddrizzare, saremmo portati a considerarlo, piuttosto che un eroe della giustizia, un maniaco pericoloso, sullo stampo di don Chisciotte o del leggendario calzolaio di Messina". CALAMANDREI, Piero. La Relatività del Concetto di Azione, p. 27.

${ }^{29}$ CALAMANDREI, Piero. La Relatività del Concetto di Azione, p. 29-30.

${ }^{30}$ CALAMANDREI, Piero. La Relatività del Concetto di Azione, p. 32.

31 CALAMANDREI, Piero. La Relatività del Concetto di Azione, p. 46.

32 JARDIM, Afrânio Silva. Direito Processual Penal. 11. ed. Rio de Janeiro: Forense, 2005, p. 85. 
níveis analíticos do crime. Assim é que a tipicidade, ilicitude e culpabilidade serão apresentadas como elementos que se afeiçoam à possibilidade jurídica do delito; a ausência de causas extintivas da punibilidade seria equivalente ao interesse jurídico e, finalmente, o Ministério Público ou o querelante, de acordo com o regime de iniciativa da ação, as partes legítimas.

Vejamos, pois na sequência, dois problemas existentes no Brasil e que dizem respeito a problemas conexos à teoria da ação.

\subsection{A Teoria Eclética da Ação}

Deveu-se a Enrico Tullio Liebman a formulação de uma teoria da ação que procurou firmar uma espécie de composição entre as matrizes concretistas e aquelas abstrativistas. Destaca-se que Liebman residiu durante vários anos no Brasil, lecionando na Universidade de São Paulo. Assim é que autores do quilate de Frederico Marques e Alfredo Buzaid passaram a difundir suas ideias, atingindo evidentemente, a geração posterior e assim sucessivamente. Liebman chega a ser tratado por Buzaid de maneira quase canônica, deificada, indicando por que seus ensinamentos eram na prática, inquestionáveis ${ }^{33}$. Esta circunstância marcou definitivamente a produção teórica no Brasil, tanto que a teoria eclética acabou por ser reconhecida com a sua adoção no Código de Processo Civil de 1973. O impacto da teoria eclética ultrapassou a seara cível. Em 2008, na reforma do processo penal, o art. 395 do CPP destaca como fator de rejeição da denúncia ou queixa a ausência das condições da ação. Deve-se registrar ainda, que a formulação definitiva da teórica eclética ocorreria apenas com o regresso de Liebman à Itália, já em 1949.

O foco de Liebman foi tentar superar os antagonismos das teorias concretas e abstratas da ação e toda a gama de variantes. Assim, a ação seria reconhecida como um direito contra o Estado. A ação seria endereçada contra o Estado pelo fato deste deter o monopólio da jurisdição ${ }^{34}$. Neste sentido a ação seria uma espécie de "direito à jurisdição" 35 , uma vez que os

\footnotetext{
33 "A vida de Enrico Tullio Liebman, conquanto tivesse sido curta a sua permanência entre nós, incorporase definitivamente na história do direito processual civil brasileiro como um marco fundamental, como um apostolado da ciência, como um templo do saber. Antes dele houve grandes processualistas, mas não houve escola; depois dele houve escola, no seio da qual floresceram grandes processualistas. Ele foi um divisor que, pondo remate a certo estilo de atividade processual, inaugurou entre nós o método científico, que os seus discípulos abraçaram apaixonadamente. BUZAID, Alfredo. Grandes Processualistas. São Paulo: Saraiva, 1982, p. 14.

34 “' $L$ 'Azione si dirige infatti verso lo Stato, nella sua qualità di titolare dela potestá giurisdizionale; ma non le sta di fronte un obbligo dell Stato stesso, perché la sua caratteristica consiste nell'essere un diritto di impulso e d'iniziativa allo svolgimento di una funzione a cui lo Stato è anch'esso interessato".
} 
conceitos de ação e jurisdição são irremediavelmente conexos e imbricados: "tra azione $e$ giurisdizione esiste perchiò esatta correlazione, non potendo aversi l'una senza l'altra" ${ }^{36}$. No pensamento de Liebman, portanto, o autor, movimentará a jurisdição (princípio ne procededat iudex ex officio), que somente existirá conquanto alguém a movimente. Esta atividade significará a mesma coisa que o exercício da ação. Veja-se que neste ponto Liebman coincide com os defensores da teoria abstrata da ação. 0 direito de ação não seria dado apenas ao autor que obtivesse êxito em sua demanda (crítica comum à teoria concretista). Mesmo uma sentença de improcedência não equivalerá a uma declaração de inexistência do direito de ação. Como se pode destacar, tanto a teoria eclética quanto a abstrata coincidirão na concepção do direito de ação como direito à jurisdição.

Não obstante, a teoria eclética da ação divergirá tanto das teorias abstratas quanto das concretas. Em que medida se pode afirmar uma superação (para Liebman e seus seguidores) das mencionadas teorias? Reconhecendo Liebman que o direito à ação estaria condicionado à satisfação de alguns requisitos preliminares ${ }^{37}$, que ficarão a meio caminho entre os pressupostos processuais e o mérito do processo. Cuida-se do que Liebman denominou de "condições da ação". Ao serem examinadas pelo magistrado, ele verá da sua presença, decidindo que o autor possui direito à ação. Apesar desta fase preliminar ser examinada pelo juiz, assevera Liebman, que não se trata de um exercício pleno de jurisdição ${ }^{38}$. Isto é, somente quando ultrapassada esta fase preliminar é que se passaria a ter uma fase verdadeiramente jurisdicional. Em conclusão, a decisão judicial de carência de ação seria uma decisão sem o caráter de jurisdicionalidade,

LIEBMAN, Enrico Tullio. L’Azione Nella Teoria del Processo Civile. In: Problemi del Processo Civile. Napoli: Morano Editore, 1962, p. 45.

35 LIEBMAN, Enrico Tullio. L'Azione Nella Teoria del Processo Civile, p. 45.

${ }^{36}$ LIEBMAN, Enrico Tullio. L'Azione Nella Teoria del Processo Civile, p. 47.

37 "Tuttavia, l'astrattezza non va intesa nel senso comumente ricevuto. Nel suo significato pieno e vero, l'azione non compete infatti a chiunque e non ha contenuto generico. Al contrario, essa si riferisce ad una fattispecie determinata ed exatamente individuata, ed è il diritto a ottenere che il giudice provveda a suo riguardo, formulando (od attuando) la regola giuridica speciale che la governa. Essa è perciò condizionata ad alcuni requisiti (che devono verificarsi caso per caso in via preliminare, anche se di solito per implicito) vale a dire all'interesse ad agire, che è l'interesse dell'attore ad ottenere il provvedimento domandato (art. $100 \mathrm{cod}$. proc. civ.); alla legittimazione ad agire, che è l'appartenenza dell'azione a colui che la propone $e$ in confronto ala controparte (art. 81 cod. proc. civ.); e alla possibilità giuridica, che è l'ammissibilità in astratto del provvedimento chiesto, secondo l enorme vigenti nell'ordine giuridico nazionale". LIEBMAN, Enrico Tullio. L'Azione Nella Teoria del Processo Civile, p. 46.

38 "In questo caso non c'è vero esercizio dela giurisdizione, ma soltanto uso delle sue forme per fare quel vaglio preliminare (affidato per necessità agli stessi magistrati) che serve ad escludere in partenza quelle cause nelle quali fanno difetto le condizioni che si richiedono per l'esercizio della potestà giurisdizionale". LIEBMAN, Enrico Tullio. L’Azione Nella Teoria del Processo Civile, p. 47. 
acarretando, a nosso juízo, um problema manifesto de lógica processual, bem como do surgimento de inúmeros problemas especialmente relacionados à temática da coisa julgada.

A ação, dirigida contra o Estado, será um direito público subjetivo, equivalente ao direito do indivíduo de obter do Estado uma sentença de mérito, capaz de resolver o conflito e trazer a segurança jurídica e a paz social por intermédio da coisa julgada. Liebman ressaltará a diferença entre o direito de petição, previsto constitucionalmente (direito de exigir dos órgãos públicos o exame de determinadas questões - art. 5, XXXIV, “a” da Constituição da República) e o direito processual de ação. Enquanto o direito de petição será absolutamente abstrato, incondicionado e ausente de qualquer restrição ao seu exercício (condições), o direito processual de ação será igualmente abstrato, embora condicionado pelo preenchimento de certos requisitos (condições da ação) $)^{39}$. Interessante notar-se aqui, em defesa da teoria eclética, o argumento corriqueiro que vislumbra o exercício incondicionado da ação como uma anomalia. Galeno Lacerda afirmará que a ausência de condições da ação levaria a um direito tão absoluto que se tornaria incapaz de legitimar o seu exercício ${ }^{40}$.

Afirma-se ainda, de acordo com a teoria eclética, que apesar de o direito de ação ser abstrato e autônomo, somente existirá uma vez presentes certos pressupostos ou requisitos, conhecidos como condições da ação. Assim, o direito de ação seria abstrato, mas "conexo a uma pretensão de direito material"41, que por sua vez pressupõe uma determinada situação fática. Este direito de ação estaria limitado por uma situação que Marques denominou como “justificada”, isto é, que apenas pode se resolver pelas vias jurisdicionais.

Ainda, segundo Marques

[...] embora autônomo e abstrato, é ele conexo a uma pretensão de direito material". Desta forma, sustenta o autor, estaria forçosamente "ligado a uma concreta situação de fato, o direito de ação na realidade só existe e se exercita quando há um motivo para a tutela jurisdicional, isto é, quando surge 'uma situação de fato contrária ao direito, que possa ser resolvida tão-só pelas vias jurisdicionais.

Aqui é importantíssimo notar que, para Marques, a ação será um direito subjetivo exercido no processo, conexo a uma situação jurídica material por uma relação de

39 LIEBMAN, Enrico Tullio. Manual de Direito Processual Civil. v I. 3. ed. São Paulo: Malheiros, 2005, p. 199.

40 "Se isto acontece com uma concepção não qualificada de petição, inteiramente despojada de atributos; se mesmo aí se vislumbram condições de exercício - que dizer de um direito de ação qualificado e estruturado em normas de direito processual?". LACERDA, Galeno. O Despacho Saneador. 2. ed. Porto Alegre: SAFE, 1985, p. 77.

${ }^{41}$ SILVA, Ovídio Baptista da. Curso de Processo Civil. v. I. 2. ed. Porto Alegre: SAFE, 1991, p. 85. 
instrumentalidade ${ }^{42}$. Note-se que assim como os pressupostos processuais indicarão a existência de uma relação jurídica processual, as condições da ação antecedem o mérito. A ação será, assim, "direito ao processo e ao julgamento do mérito" ${ }^{43}$. Trata-se de um direito que não tem por objetivo garantir a favorabilidade da sentença.

De acordo com Liebman ${ }^{44}$, três serão as condições da ação: a) a legitimidade das partes; b) o interesse de agir; c) a possibilidade jurídica do pedido. Elas serão apresentadas como "condições de admissibilidade do julgamento da demanda, ou seja, como condições essenciais para o exercício da função jurisdicional, com referência à situação concreta" ${ }^{45}$.

A primeira condição da ação corresponde à legitimidade das partes (legitimatio ad causam). A legitimidade das partes cuida-se de elemento que consiste no procedimento de individualização do portador do interesse de agir e contra quem este interesse será endereçado. O direito, portanto, de invocar a jurisdição, apenas poderá ser deflagrado a partir da parte autora que reclama para si uma relação jurídica da qual pleiteia tutela ${ }^{46}$.

A segunda condição da ação é o interesse de agir, consistente no interesse em obter o provimento final. Trata-se, segundo Liebman, do "elemento material do direito de ação"47. 0 interesse de agir será um interesse processual, secundário e instrumental em relação ao interesse substancial primário. Seu objeto é o provimento endereçado ao juiz para a satisfação daquele interesse primário violado pelo comportamento do réu. Não se pode olvidar, de acordo com Liebman, que o interesse de agir decorre da necessidade de se obter, com o processo, a proteção do interesse primário. Somente a partir desta premissa é que se poderá reconhecer que o interesse dependerá da aptidão do provimento solicitado para a satisfação do interesse primário. Trata-se, portanto, de uma relação de utilidade entre o provimento e o interesse substancial primário. Nas palavras de Liebman, “o interesse de agir é representado pela relação entre a situação antijurídica denunciada e o provimento que se pede para debelá-la mediante a aplicação do direito"48.

Finalmente, a terceira condição da ação que, embora abandonada por Liebman, foi mantida pela doutrina civil e, simultaneamente, aceita pela penal. A possibilidade jurídica do

\footnotetext{
${ }^{42}$ MARQUES, José Frederico. Instituições de Direito Processual Civil. v. II. 3. ed. Rio de Janeiro: Forense, 1966, p. 27.

${ }^{43}$ LIEBMAN, Enrico Tullio. Manual de Direito Processual Civil, p. 200.

44 Importante observar que após a terceira edição do Manuale as condições da ação foram resumidas a duas: (a) legitimidade para a ação e (b) interesse de agir.

45 LIEBMAN, Enrico Tullio. Manual de Direito Processual Civil, p. 203.

46 LIEBMAN, Enrico Tullio. Manual de Direito Processual Civil, p. 209.

47 LIEBMAN, Enrico Tullio. Manual de Direito Processual Civil, p. 206.

48 LIEBMAN, Enrico Tullio. Manual de Direito Processual Civil, p. 207.
} 
pedido era apresentada por Liebman como a admissibilidade em abstrato do provimento requerido. Assim, se o pedido demandar do juiz a emissão de uma sentença ilógica, absurda, impossível, não faria jus o autor à ação. Como exemplos, seria possível se afirmar que não haveria possibilidade jurídica do pedido àquele que postulasse uma ação de usucapião relatando na inicial que não possui o prazo legal previsto para a aquisição da propriedade, mas pedindo ao juiz que a conceda bem como aquele que requer ao magistrado, por exemplo, o direito de furtar bens da propriedade de seu vizinho.

Vista em linhas gerais as bases sobre as quais se consolidaram a maneira de se estudar o processo no Brasil ao longo do século XX, deve-se necessariamente apresentar as profundas objeções à teoria liebmaniana. Preocupamo-nos em aprofundar naturalmente as críticas em relação à teoria eclética, tendo em vista que as teorias da ação anteriormente expostas - mais em caráter pedagógico - não possuem, no Brasil, adesão significativa da doutrina e jurisprudência.

Preliminarmente, é lugar comum a crítica à teoria eclética a partir da afirmação de Liebman de que o juiz, quando decide pela carência de ação, não exerce jurisdição. Trata-se, como se disse, da crítica mais facilmente constatável no edifício teórico do processualista italiano. ${ }^{49}$ Entretanto nosso foco diz com a problemática processual penal, em que a sua transposição, além de não reparar este problema, o acentua. Como, por exemplo, regular a análise das condições da ação por órgão não-jurisdicional? No processo penal, o exercício jurisdicional é inarredável, em qualquer hipótese. Seja pelo fato de que o acusado precisa poder se manifestar sobre a acusação, perante órgão jurisdicional, seja pelo princípio da necessidade

\footnotetext{
${ }^{49}$ Neste ponto, destaca Fairén Guillén (Estudios de Derecho Procesal. Madrid: ERDP, 1964, p. 79) que se a jurisdição apenas se inicia com a presença manifesta das condições da ação, além de não se saber em que posição se encontra o juiz (administração, legislativo, executivo, judiciário), não se torna possível saber tampouco quando se está diante de um processo ou qualquer outra atividade. De fato, descaracterizar a análise das condições da ação como uma mera filtragem, como afirma Liebman e seus seguidores é inicialmente, "administrativizar" a função jurisdicional. Alguns seguidores, radicalizando ainda mais o pensamento de Liebman, sugeriram a criação de um novo poder, unicamente para a execução da tarefa (Cf. MESQUITA, Botelho de. Da Ação Civil. São Paulo: Revista dos Tribunais, 1975, p. 94 e ainda BORGES, José Afonso. Inépcia da Petição e Direito de Ação. Revista Forense, n. 138. Rio de Janeiro, 1951. p. 315). Neste ponto, a teoria eclética da ação se constitui como uma teoria arbitrária (a ausência de exercício de jurisdição nestes casos, pelo juiz, parece-nos mais um sintoma da tentativa de conciliar as teorias abstratas com as concretistas) e evidentemente, marcada por um cariz autoritário inegável. Isto pelo fato de além de diminuir o âmbito jurisdicional, relativiza direito fundamental (direito ao acesso aos tribunais) pela via inadequada da insuperável ausência de jurisdição. Calmon de Passos, em célebre argumento, questiona que, em caso de inépcia da inicial, havendo agravo e recurso extraordinário, em caso de manutenção da decisão, teríamos a última e máxima instância jurisdicional decidindo sem haver ação e, inexoravelmente, sem haver jurisdição (PASSOS, José Joaquim Calmon de. A Ação no Direito Processual Civil Brasileiro. Salvador: Oficinas Gráficas da Imprensa Oficial da Bahia, 1960, p. 27).
} 
do processo em relação à pena (nulla poena sine juditio). ${ }^{50}$ Mas há mais problemas que precisam ser apontados.

Segundo Silva, um dos grandes erros da teoria eclética, compartilhado com a teoria do direito concreto de ação, reside na confusão entre direito subjetivo e ação e entre direito subjetivo e pretensão ${ }^{51}$. Há um inequívoco problema terminológico empregado pela doutrina, que confunde o conceito de ação processual e o direito (subjetivo) de acesso aos tribunais. 0 direito de acesso aos tribunais é o direito subjetivo, que evidentemente não se confunde com o exercício de ação. Trata-se de um status que precede o exercício do próprio direito, mediante a ação. Assim sendo, não resta dúvida de que este direito de acesso aos tribunais é um direito abstrato (outorgado a todo indivíduo, indistintamente). Logo, a ação que o tutela não pode possuir natureza diversa daquela do próprio direito da qual emana. Trata-se, também, a ação, de um direito abstrato ${ }^{52}$, pela simples razão de o direito de acesso aos tribunais também o ser.

O direito subjetivo pode ser concebido como uma determinada situação jurídica de favorabilidade de um sujeito em relação a outro. Por se tratar de uma posição assumida por um sujeito em relação a outro, note-se que o direito subjetivo goza de certa estática. 0 direito do credor em relação ao devedor constitui-se como um direito subjetivo. Todavia, o simples fato de alguém possuir um direito subjetivo em relação a outrem não se confunde com a satisfação deste direito. Quem possui uma obrigação a termo, cujo prazo ainda está por expirar possui um direito subjetivo, mesmo que não possa exigir o cumprimento da obrigação. Faltará ao credor a exigibilidade, que nas lições de Pontes de Miranda, será a pretensão ${ }^{53}$. Para Pontes de Miranda, a posição de um sujeito em relação a outro, de the poder exigir uma prestação positiva ou negativa, equivalerá à pretensão. A pretensão é “a faculdade de se poder exigir a satisfação do direito" 54 . Há uma verdadeira confusão entre o direito subjetivo e a faculdade de exigir,

\footnotetext{
${ }^{50} \mathrm{O}$ que mais parece irredutível na afirmação do caráter jurisdicional da análise aparece no conteúdo da própria Súmula 707 do STF (constitui nulidade a falta de intimação do denunciado para oferecer contrarrazões ao recurso interposto da rejeição da denúncia, não a suprindo a nomeação de defensor dativo). Em síntese, bastaria esta primeira crítica que é de uma contundência irrebatível para abandonarmos a teoria eclética.

51 SILVA, Ovídio Baptista da. Curso de Processo Civil. v. I. 2 ed. Porto Alegre: SAFE, 199, p. 83.

52 SILVA, Ovídio Baptista da. Curso de Processo Civil, p. 84.

53 “A ação, que supõe haver-se transgredido a norma, constitui outro plus e tende, não à prestação, mas ao efeito jurídico específico. $O$ credor tem direito subjetivo ao que se the atribui: tem-no, desde que a relação nasceu. A exigibilidade faz-lhe a pretensão. Se o devedor não paga como e quando deve pagar, cabe-lhe, então, a ação". MIRANDA, Pontes de. Comentários ao Código de Processo Civil. Rio de Janeiro: Forense, 1973, p. 122.

${ }^{54}$ SILVA, Ovídio Baptista da. Curso de Processo Civil, p. 62.
} 
tributável a Thon, para quem a norma jurídica estabelece deveres e não direitos ${ }^{55}$. A pretensão será o direito subjetivo em sua faceta dinâmica, em sua motricidade. Entretanto, segundo as lições de Pontes de Miranda, o exercício da pretensão não é ainda agir (aquele que se limita a exigir não age). A pretensão será um meio para um fim (satisfação do direito subjetivo). Contudo, a exigência, que não coincide com a ação, depende de um comportamento voluntário do obrigado. O direito subjetivo, em caso de cumprimento do obrigado, será satisfeito sem o recurso à ação. A ação de direito material, como afirma Silva, será um agir do titular do direito para a realização do direito subjetivo, independentemente do comportamento do obrigado ${ }^{56}$. A grande parte da doutrina não dá muita importância ao conceito de direito material de ação, tendo em vista o monopólio do poder jurisdicional do Estado. Desta forma, a ação de direito material passou a ser entendida como um agir do titular para a sua própria satisfação para um “fazer agir", que seria apenas a atividade do sujeito do direito deflagradora da atividade jurisdicional ${ }^{57}$. Nessa linha, inclusive o conceito de jurisdição foi relegado a um mero pronunciamento, como vimos, na concepção de Marques.

Há grandes impropriedades neste cenário. 0 primeiro grave equívoco provocado pela supressão do direito material de ação vem estampado no pensamento de Pekelis ${ }^{58}$, para quem a antiga actio se havia transformado em uma não-ação, a partir da criação do Estado romano e do surgimento do monopólio da jurisdição. Assim, a proibição do titular do direito de agir pessoalmente seria o fenecimento da ação de direito material. 0 provimento jurisdicional contém, além de uma declaração, uma ação ontologicamente idêntica àquela pessoal a ser exercida pelo titular do direito. Assim, antes de haver a supressão da ação de direito material, haveria a sua realização pelos órgãos jurisdicionais ${ }^{59}$. Essa sucessão de equívocos sobre 0 conceito de direito material de ação, que foi transferido ao Estado pelo monopólio da jurisdição, permitiu a incorreta compreensão de que o direito material de ação se resume ao direito de acesso aos tribunais, coisa completamente diversa.

Da violação de um direito subjetivo, tem-se a pretensão e o direito material de ação. 0 direito de acesso aos tribunais é igualmente um direito subjetivo, cujo exercício depende da ação enquanto movimento, como exercício do direito subjetivo, estático.

\footnotetext{
55 THON, August. Norma Giuridica e Diritto Soggetivo: indagini di teoria generale del diritto. 2. ed. Padova, 1951, p.12.

${ }^{56}$ SILVA, Ovídio Baptista da. Curso de Processo Civil, p. 63-64.

57 SILVA, Ovídio Baptista da. Curso de Processo Civil, p. 67.

58 PEKELIS, Alessandro. Azione, p. 34.

59 SILVA, Ovídio Baptista da. Curso de Processo Civil, p. 67.
} 
Exclusivamente analisada sob o ângulo do processo penal, a teoria eclética da ação promove uma verdadeira inversão da carga probatória. Destacam Gomes e Silva que Liebman foi acusado de criar uma teoria privatista da ação, uma vez que a conclusão judicial da existência das condições da ação invariavelmente conduziria a uma sentença de mérito procedente ao autor. De fato, uma vez que as partes são legítimas, o pedido é juridicamente possível e há interesse de agir, resta apenas a decisão de procedência ${ }^{60}$. Na tentativa de escapar desta crítica, Liebman e os defensores da teoria eclética responderam que o juiz deve apenas lidar com juízos hipotéticos, presumindo-se verdadeiros os fatos articulados pelo autor, que não deve atentar para as consequências concretas de sua decisão.

Veja-se que é somente através de raciocínios apriorísticos e por nada concretos que o juiz deve examinar as condições da ação. É absolutamente ingênuo que possa um juiz examinar as condições da ação como completamente desligadas do mérito. Trata-se de um pensamento veihingeriano do als ob (do como se) enfraquecido. ${ }^{61}$ Não é difícil se concluir que, levadas avvant la lêttre, as instruções de Liebman ao processo penal, no momento do recebimento da denúncia o magistrado deverá "presumir ser o acusado o autor do crime", haver materialidade, tipicidade e todos os elementos do delito. Não apenas se trata de um juízo humanamente impossível, como a estrutura do processo penal é diversa: exige-se justa causa para o recebimento da denúncia justamente pelo fato de o processo penal ser uma pena em si mesmo. Exige-se a justa causa no escopo de se reduzir danos (irreparáveis) decorrentes do processo penal. Exige-se que o juiz rejeite a denúncia quando estiver em dúvida com relação à possibilidade da prática do crime. Todo o contrário do que a teoria eclética promove desde a sua interioridade.

Outra crítica que não pode ser desprezada no exame da teoria eclética reside na tentativa de conciliação, de laços de conexão entre as teorias abstratas e concretas e, mais problematicamente, entre o direito processual e o material. Neste sentido já advertia Pekelis a respeito de uma teoria unitária. Veja-se que as condições da ação seriam espécies de ponte entre o plano processual e o material, como sustenta Galeno Lacerda. ${ }^{62}$ Do oposto, já demonstramos serem a ação de direito material e a ação processual fenômenos inconfundíveis. A epidérmica tradição processual que afirma que a ação de direito material foi suprimida pela

\footnotetext{
${ }^{60}$ SILVA, Ovídio Baptista da; GOMES, Fábio Luiz. Teoria Geral do Processo Civil, p. 116.

61 Para Barbosa Moreira, "deve [o juiz] raciocinar como quem admita, por hipótese e em caráter provisório, a veracidade da narrativa, deixando para a ocasião própria (juízo de mérito) a respectiva apuração, ante os elementos de convicção ministrados pela atividade instrutória" (MOREIRA, J. C. Barbosa. Legitimação Para Agir. Indeferimento da Petição Inicial. In: Temas de Direito Processual. São Paulo: Saraiva, 1994, p. 200).

62 LACERDA, Galeno. Ensaio de uma Teoria Eclética da Ação. In: Revista da Faculdade de Direito de Porto Alegre. Porto Alegre, 1958, p. 93.
} 
ação processual cuida de institutos e categorias diversas. A confusão de Liebman relativamente aos dois planos é o que permite esta conclusão.

No plano do processo penal temos uma situação ainda mais grave. Não se pode descurar que a concepção de pretensão punitiva como o objeto do processo penal é uma comistão de conceitos logicamente não comungáveis. E que revela como a supressão do direito material foi repristinada no objeto do processo. Lamentavelmente, a doutrina processual penal insiste em repetir conceitos estéreis (mais adiante será analisado tal problema).

Uma penúltima crítica se faz necessária. A teoria eclética, a fim de esgrimir-se das críticas que atingem em cheio sua estrutura, afirma que o réu também possui direito à ação. Se a teoria eclética parte do conceito de que ação é o direito a uma sentença de mérito, sendo inegável que o réu também possui este direito, não houve alternativa a não ser reconhecer o réu como titular do direito de ação. No mesmo sentido de Liebman, incorre Monacciani na afirmação de que o réu é tão titular do direito de ação quanto o autor, isto é, “un vero e proprio diritto di $a^{a} i o n e^{63}$ ". Aí se encontra, novamente, uma grave confusão entre ação e pretensão ${ }^{64}$. Que dizer do processo penal? A resposta do acusado frente à denúncia constituiria uma ação penal? Quiçá uma espécie de ação declaratória negativa? Uma vez mais se percebe o equívoco da teoria. Ademais, deve-se dizer que Liebman adere ao conceito de lide, inclusive tirando a partir disso inextricáveis consequências. Como veremos a seguir, podemos apenas concluir antes pela inexistência de lide no processo penal, como demonstra, com acerto, Coutinho ${ }^{65}$.

\title{
2.2 O Objeto do Processo Penal
}

\begin{abstract}
${ }^{63}$ MONACCIANI, Luigi. Azione e Legitimazione. Milano: Giuffrè, 1951, p. 363.
64 "Ora, direito de ação, como equivalente à pretensão de tutela jurídica, tanto o autor quanto o réu possuem, pois também este tem direito à sentença de mérito. De qualquer forma, a premissa lógica, de que se parte, sustenta-se no pressuposto de ser autor aquele que age; e réu aquele que sofre a ação do autor e, pois, reage. Ser réu é sofrer a ação do autor e dela defender-se. Dizer-se que o réu exerce também uma ação é um disparate lógico a denunciar o equívoco em que os defensores desta posição laboram, pela confusão entre o conceito de ação de direito material e os conceitos de 'pretensão de direito material', 'pretensão de tutela jurídica', que é pré-processual, e 'ação' processual. 0 réu, por definição, não exerce ação, opõe reação à ação do autor. Contudo, tanto o autor quanto o réu têm idêntica 'pretensão de tutela jurídica', uma vez que também a este reconhece a ordem jurídica o direito ao pronunciamento sobre o pedido formulado pelo autor. Ambos podem exigir a resposta jurisdicional (exercer pretensão, inconfundível com o agir = exercer ação). $\mathrm{E}$ como essa virtualidade de que se reveste o direito, identificada com o poder exigir, dá-se o nome de pretensão, tem de se distinguir a exigibilidade frente ao Estado, que se atualiza por meio da 'ação', da outra exigibilidade, de direito material, contra o obrigado". SILVA, Ovídio. Ação de Imissão na Posse. 3. ed. São Paulo: Revista dos Tribunais, 2001, p. 23. ${ }^{65}$ COUTINHO, Jacinto Nelson de Miranda. A Lide e o Conteúdo do Processo Penal. Curitiba: Juruá, 1989.
\end{abstract}


Alguma tradição sistematizada, ao menos desde Arturo Rocco, não se pode deixar perder. Desde os seus trabalhos que vieram à luz em 1932, ele apõe a um objeto que é a pena (desde uma concepção plenamente legitimada) a sustentação conceitual autoritária de um direito subjetivo de castigar (ius puniendi). A determinação técnico-jurídica (que inspirou o código de processo penal italiano de 1930 - de enorme valência para a nossa normativa processual penal de 1941) do conceito de direito de punir como direito subjetivo está, segundo ele, estreitamente conectada com a relação jurídica que se estabelece entre Estado e réu. ${ }^{66} \mathrm{Em}$ geral, este direito subjetivo de punir seria um poder político penal disciplinado pelas normas de direito penal convertido agora num poder jurídico de acionar a busca por este objetivo.

Aparece, desta maneira, o direito de punir como um direito subjetivo público (do Estado) atrelado, segundo o autor, a um particular direito de supremacia, ou seja, derivado de um status geral de subordinação e obediência política frente ao ente estatal. Por evidente que, neste contexto, o objeto deste direito de punir é a pessoa do súdito enquanto autora da violação de um preceito jurídico penal: “el derecho de punir es, pues, un derecho sobre otra persona"67. A sujeição ao Estado da pessoa do réu deve ser tão completa, segundo afirma, que chega a destruir a sua personalidade. Conjugam-se na pessoa do réu, agora não somente a caracterização de objeto, mas também de sujeito passivo do direito de punir do Estado: “el derecho de punir se explica así, en un determinado momento, respecto del reo y hacia el"68. É este momento de direito sobre o réu que será chamado de pretensão jurídica (punitiva). E a ela corresponde uma obrigação - uma relação jurídica de caráter obrigatório (um dever jurídico) é estabelecida. Relação jurídica obrigatória, afinal punitiva, a que está obrigada a pessoa do réu. Se por um lado a norma atribui ao Estado uma pretensão punitiva, por outra parte impõe ao delinquente um correlato dever jurídico que repousa no interesse de se submeter à pena: “uno de ellos es la pretensión jurídica penal (...), el otro, el correspondente deber jurídico del reo de someterse obligatoria y coactivamente a la pena." ${ }^{69}$.

Ademais de ser o direito subjetivo de punir o exercício de uma exigência como pretensão, naturalmente, desde este ponto de vista, pouco afeito aos acordes democráticos,

\footnotetext{
${ }^{66}$ Antes disso, há que se recordar que a trilha foi aberta por Karl Binding. Como escreve Rocco: "derecho subjetivo de punir (ius puniendi) es la faculdad del Estado de accionar en conformidad con las normas de derecho (derecho penal, en sentido objetivo) que garantizan el alcance de su objeto punitivo y de pretender para otros (reo) esto a que está obligado por fuerza de las mismas normas." ROCCO, Arturo. Sobre el Concepto del Derecho Subjetivo de Punir. In: Cinco Estudios sobre Derecho Penal. ROCCO, Arturo. Montevideo-Buenos Aires: B de f-Euros, 2003, p. 17.

${ }^{67}$ ROCCO, Arturo. Sobre el Concepto del Derecho Subjetivo de Punir. p. 19-22.

${ }^{68}$ ROCCO, Arturo. Sobre el Concepto del Derecho Subjetivo de Punir. p. 26.

${ }^{69}$ ROCCO, Arturo. Sobre el Concepto del Derecho Subjetivo de Punir, p. 31.
} 
trata-se de um interesse coletivo ou social, essencialmente preventivo que se exerce mediante a repressão, na senda das mais obtusas teorias de legitimação penal. A atuação para a punição do réu torna-se um dever que o Estado tem de cariz ético ou moral, pertinente, como quer o autor italiano, às categorias dos chamados direitos cívicos. ${ }^{70}$ Assim, para tal sustentáculo de um processo penal fascista, estaríamos frente a um direito subjetivo público que o Estado passaria a ter diante do desrespeito de alguém frente a uma norma de direito material.

O processo penal estaria aí meramente para realizar uma pretensão punitiva nascida da violação da norma penal (da lesão ao bem jurídico), longe de qualquer idéia sobre a máxima eficácia dos direitos fundamentais. Por esta exigência, o Estado, pelo Ministério Público, passaria a ser credor, tal como no direito privado (processo civil), de uma pena a ser adjudicada mediante o processo penal, visto apenas como instrumento de tutela daquele direito subjetivo de punir. A passos largos, vamos na direção esquizofrênica de um Estado autoritariamente detentor de um triplo direito: um punitivo, um de ação penal e um de sentenciar. Dentre outras, por esta razão a crítica profunda de Goldschmidt quanto à exigência punitiva de Binding: “la consecuencia jurídica del Derecho penal no es la pena, sino el derecho subjetivo de penar y (...) este derecho no puede ejercerse fuera del proceso. ${ }^{71} \mathrm{E}$ a isto estamos presos até os dias atuais, sobre materiais os quais se constrói um processo penal autoritário. Veja-se a simples atribuição da existência de lide no processo penal, mal sabendo-se o que isto atrela: como é que falaremos nela se, da lesão ao bem jurídico, não se deduz um ius puniendi, mas uma pretensão acusatória, um poder de submeter alguém a um processo? Muito menos haverá qualquer direito a ser adjudicado desde uma exigência punitiva, afastando-se qualquer reminiscência de conflito de interesses (senão acriticamente) entre ius puniendi e status libertatis - vide a pretensão punitiva que segue sendo amplamente aceita nas lições doutrinárias. ${ }^{72}$

A posição epistemológica do processo penal, a rigor, é que está em cheque para pensá-lo autônomo e diferenciado, daí a crítica à lide ganha importância radical. Mesmo que o processo acusatório tenha se configurado segundo o modelo do processo civil, como um actus trium personarum, o sentido desta medida política não deve fazer o processo penal ser visto mecanicamente desde o processo civil, pois fundamental compreender que - já se disse -, no processo penal, a situação da parte ativa é completamente diferente da do autor no processo

\footnotetext{
${ }^{70}$ ROCCO, Arturo. Sobre el Concepto del Derecho Subjetivo de Punir, p. 40.

71 GOLDSCHMIDT, James. Problemas Jurídicos y Políticos del Proceso Penal: Conferencias dadas en la Universidad de Madrid en los meses de diciembre de 1934 y de enero, febrero y marzo de 1935. Barcelona: Bosch, 1935, pp. 22 e ss. (cit. p. 26).

72 Grande parte, sobremaneira, vão beber nas lições de MARQUES, José Frederico. Elementos de Direito Processual Penal. Volume I. São Paulo: Forense, 1961, pp. 305-316.
} 
civil. O Ministério Público não pode fazer valer no processo penal um direito próprio através da sua adjudicação, tal como aquele autor do processo civil, senão como afirma Goldschmidt, que "afirma el nacimiento del derecho judicial de penar y exige el ejercicio de este derecho que al mismo tiempo representa un deber" do Estado, pois ele é o detentor do poder de punir representado na figura do juiz que apenas se realizará via processo ${ }^{73}$. 0 esforço para o processo penal construir categorias próprias não pode cessar - questão de honestidade democrática e opção política. ${ }^{74}$

Sabido que o conceito de lide de Carnelutti teve singular importância na construção de elementos comuns aos tipos processuais de uma "teoria geral do processo", importantíssimo não olvidar que fora ultrapassada inclusive pelo próprio mestre italiano. ${ }^{75}$ Há de se aclarar, ao menos, as três alterações nítidas no pensamento de Francesco Carnelutti sobre a lide. Afirmavase na doutrina a manutenção da regra sobre o conteúdo do processo penal como um conflito de interesses, e a discussão maior ficava por conta da natureza destes. É em 1936, no seu Sistema di Diritto Processuale Civile, que começa a propor uma roupagem nova aos institutos, a começar pela pretensão, agora vista como a "esigenza della subordinazione dell'interesse altrui all'interesse proprio", tentando assim construir um novo conceito de lide mais afeito a uma construção unitária e precisa: "chiamo lite il conflitto di interessi qualificato dalla pretesa di

73 GOLDSCHMIDT, James. Problemas Jurídicos y Políticos del Proceso Penal, p. 28.

74 "por primário, não se há de construir uma teoria, muito menos geral, quando os referenciais semânticos são diferentes e, de consequiência, não comportam um denominador comum. Pense-se só nos casos citados, ou seja, entre DPP e DPC o princípio unificador, o sistema e o conteúdo são distintos, resultando daí uma TGP plena de furos e equívocos, alguns intransponíveis, no DPP naturalmente. Urge, portanto, uma teoria geral do direito processual penal arredia à falta de ensancha da teoria geral do direito processual civil, pelo menos para poder-se ter uma base mais coerente no momento de uma reforma que pretenda não ser só de verniz." (COUTINHO, Jacinto Nelson de Miranda. Efetividade do processo penal e golpe de cena: um problema às reformas processuais. In: Escritos de Direito e Processo Penal em homenagem ao professor Paulo Cláudio Tovo. WUNDERLICH, Alexandre. Rio de Janeiro: Lumen Juris, 2002, p. 140). A despeito das errôneas analogias com o processo civil que ainda dominam o cenário até hoje, em virtude da tão prolatada Teoria Geral do Processo (desde a lide carneluttiana, difundida no Brasil por Liebman como conteúdo do processo penal, no pós-guerra, pela Escola Paulista de Processo (ALCALÁ-ZAMORA Y CASTILLO, Niceto. Estudios de Teoría General e Historia del Proceso (1945-1972). Tomo II ( $\left.n^{\circ} 12-30\right)$. México: Universidad Nacional Autônoma de México, 1992, pp. 527-528), Figueiredo Dias escreve: "o tempo das grandes teorias gerais parece ser, para o pensamento jurídico, um tempo definitivamente passado, por nelas estar latente o perigo de quebrarem a relacionação, que cada vez se quer mais próxima e estreita, da ordem jurídica com a vida e a realidade social que aquela procura servir" (DIAS, Jorge de Figueiredo. Direito Processual Penal. Clássicos Jurídicos (1 ${ }^{\mathrm{a}}$ ed. 1974). Reimpressão. Coimbra: Coimbra, 2004. p. 54; cf., no mesmo sentido, CONSO, Giovanni. Istituizioni di Diritto e Procedura Penale. Milano: Giuffrè, 1964, pp. 3-4). No Brasil, há que se destacar o pioneirismo de Tucci quanto à crítica da teoria geral do processo, especialmente quanto a "civilizar" o processo penal (cf. TUCCI, Rogério Lauria. Teoria do Direito Processual Penal. p. 54).

75 Cf. esta trajetória e a necessária acepção do caso penal como conteúdo do processo penal, ver COUTINHO, Jacinto Nelson de Miranda. A lide e o conteúdo do processo penal. Curitiba: Juruá, 1989. 
uno degli interessati e dalla resistenza dell 'altro". Ao processo penal, nada difícil seria então demonstrar a existência de um conflito de interesses, "non può essere dubbio che in fondo del processo penale sia costituto dal conflitto di interessi tra l'imputato e la parte lesa. (...) Dunque il conflitto di interessi dev'essere qualificato da una pretesa contro l'imputato; altrementi il processo non avrebe ragione".

A mudança mais sentida em Carnelutti, porém, que se opera no processo penal - depois das polêmicas com Piero Calamandrei, Giulio Paoli e Francesco Invrea - vem em 1941, quando nas Istituzioni del Processo Civile Italiano (mesmo que mantida a estrutura da posição anterior) assume uma postura menos rígida e decisiva, desestabilizando, de certa maneira, a sua tão sonhada teoria geral do processo. Reconhecendo o erro anterior, passava naquele momento a explicar a situação do processo penal de maneira diversa, colocando-o numa "posizione intermedia tra il processo contenzioso e il processo volontario", ainda assim vislumbrando a existência de um conflito entre o imputado e o Estado, este titular de um interesse público de impor a sanção penal fazendo valer-se da exigência de subordinação do interesse do réu ao estatal, tal a presença da pretensão punitiva. De maneira aproximada, eis aí a forma como a recepção da lide penal, como um conflito de pretensões, simples e sinteticamente, entre jus puniendi e status libertatis, imprescindível ao processo penal, estabilizou-se. 0 juiz comporia um litígio de interesses entre Estado e o cidadão, aquele detentor do direito punitivo, que o faz valer mediante sua pretensão através do seu órgão competente que é o Ministério Público, esta aparecendo quando a norma incriminadora é violada.

Contudo, de primeira edição em 1946, é nas Lezioni sul processo penale que Carnelutti avança sobre os erros das duas posturas anteriores (aquele do caráter contencioso e depois aquele do tipo intermediário entre processo contencioso e voluntário acerca do processo penal). Ali desaparece por completo a lide no processo penal para o Mestre italiano, o tal conflito de interesses, e sem ele não poderia o processo penal ser considerado contencioso. Assim, no seu novo arreglo, o processo teria assim um caráter misto, isto é, seria contencioso quanto ao processo civil e voluntário em relação ao penal. Afasta-se, a rigor, de uma teoria unificada de processo. ${ }^{76}$

\footnotetext{
${ }^{76}$ Sobre as fases concebidas do raciocínio de Carnelutti, donde extraíram-se as citações no original, cf. COUTINHO, Jacinto Nelson de Miranda. A lide e o conteúdo do processo penal, pp. 82-106. No mesmo tom e da mesma época (1946) é outro texto paradigmático de Carnelutti a confirmar sua nova condição, no qual adverte, não só para o papel secundário do processo penal diante do próprio direito penal, mas principalmente para a inferioridade da ciência do processo penal em comparação à ciência do processo civil, advogando uma paridade entre ambas. Certamente, como já atestava o mestre italiano, cerca de noventa por cento do trajeto do processo penal vem da adaptação ao seu fenômeno de conceitos
} 
Feitas tais observações, agora, sim, já estamos em condições de fluir sobre terreno por demais movediço, que serve à definição dogmática das funções de acusação e, naturalmente, diz respeito ao abismo sobre o qual se debruça a delimitação do objeto/conteúdo do processo penal. Ademais, em comunhão de esforços, há de se destacar, a profunda análise, para além do senso comum corrente da pretensão punitiva de Karl Binding, a construção do objeto do processo penal, como faz Lopes Jr., desde Guasp, Goldschmidt e Gómez Orbaneja acerca da pretensão processual acusatória: uma declaração petitória de que existe o direito potestativo de acusar e que procede a aplicação do poder punitivo do Estado como objeto do processo penal ${ }^{77}$.

Acompanhando o argumento, pode-se dizer sinteticamente que no processo penal o acusador exerce o ius ut procedatur. Dirá Gomez Orbaneja junto com Herce Quemada, definindo a ação penal como uma faculdade de iniciativa processual: "la acción como el derecho meramente formal de acusar. Mediante la acusación no se hace valer una exigencia punitiva, sino se crea tan sólo el presupuesto necesario para que el órgano jurisdiccional pueda proceder a la averiguación del delito y de su autor e imponer la pena al culpable."78 Claro que neste ponto há uma recusa ao modo tradicional de analisar a ação, não necessariamente sobre a essência do poder jurídico a que a ação está vinculada, mas, repita-se, sob o prisma de sua verdadeira função formal. Quer dizer, há um direito abstrato ao processo, o direito potestativo de acusar (pretensão acusatória) - nada de direito subjetivo de punir nascido da violação de uma norma incriminadora de direito material - sim, um poder de proceder contra alguém, desde que

construídos para o estudo do processo civil, um pancivilismo, na esteira de Bettiol, que coloca a teoria do processo penal na nítida dependência de esquemas importados do processo civil (antes disso, não esqueçamos que fora o pancivilismo, como atesta Guarneri, antes mesmo em matéria de direito penal, o trajeto por muito tempo trilhado por Carnelutti, a saber, em especial no estudo do delito aplicando-se conceitos do negócio jurídico, o que retratava a luta hercúlea devido ao desenvolvimento relativamente tardio da ciência penal frente às ciências romano-civilistas e a tendência destas úlitmas de imporem-se sob os demais ramos do conhecimento jurídico. Sobre o panorama, ver GUARNERI, Jose. Las Influencias del Derecho Civil en el Derecho Penal (Ensayo sobre alguns conceptos de la parte general de Derecho Penal). Puebla: Publicaciones de la Universidad de Puebla, s/d., pp. 17-19). Mas, em sua maturidade, o processo penal será visto em sua fraca identidade, tal como a fábula infantil da Cinderela, como aquela que "giusto, si contentava delle vesti smesse dalle sue più fortunate sorelle." Em geral, as razões deste desleixo dizem respeito à aparência de cada processo: enquanto o processo civil é um processo de possuidores, ou ao menos de quem aspira possuir algo, "è il processo del mio e del tuo", no processo penal o que está posto em jogo não é apenas a propriedade, mas trata-se da liberdade. No âmbito civil se discute, enfim, quanto ao ter e no penal quanto ao ser e, numa sociedade como a nossa, "chi tra noi riesce a pregiare piuttosto l'essere che l'avere?" (CARNELUTTI, Francesco. Cenerentola. Rivista di Diritto Processuale. Num. 3-4 - P. I. Padova: CEDAM, 1946. pp. 75-76 e 78).

77 LOPES JR., Aury. Direito Processual Penal e sua Conformidade Constitucional. Volume I. 5 ed.. Rio de Janeiro: Lumen Juris, 2010, pp. 85-113.

78 GÓmEZ ORBANEJA, Emilio; HERCE QUEMADA, Vicente. Derecho Procesal Penal. 10. ed. Madrid: Artes Gráficas y Ediciones S. A., 1987, pp. 89-90. 
presentes os requisitos legais; e, de outro lado, é o juiz que detém o poder de punir, condicionado ao exercício integral e procedente da acusação.

Por certo, ainda, reformulado o conceito de pretensão carneluttiana por Guasp ${ }^{79}$, conclui-se ser o objeto do processo penal a pretensão acusatória (de titularidade do Ministério Público ao qual corresponde um poder de invocação): significa apontar a existência de uma faculdade de solicitar a tutela jurisdicional, a se afirmar ou não a existência de um delito, para apenas assim poder ver-se concretizado o poder punitivo aplicado pelo juiz. Enfim, pensa-se a pretensão acusatória desde uma declaração petitória de que existe o direito potestativo de acusar. Ao acusador corresponde um poder de invocação. O que se deve acentuar, sobretudo, é o contorno daquilo que já vimos chamado direito de ação, seus elementos e componentes, para que pudesse ficar aproximada a zona de conflito sobre a qual o magistrado não deve trafegar. Noutros termos, ele não poderá se debruçar sobre atividades de persecução, que contribuam, sustentem, mantenham ou digam respeito ao direito potestativo de acusar, sítio próprio do Ministério Público (caso exemplar é a proibição que daí decorre quanto ao juiz condenar quando o Ministério Público pede a absolvição, ao contrário do que permite nosso sistema processual no art. 385 do (PP). Poder-se-ia dizer, ao negativo, como força de argumento: estará apto a julgar, ou poderá decidir o magistrado quando não tiver exercido função de parte, quer dizer, quando não acumular poderes persecutórios, mesmo que indiretamente, e de julgamento.

\section{CONCLUSÃO}

Como força de sintética conclusão, tentar fugir, não obstante, da concepção de lide carneluttiana e dos grilhões de uma teoria geral do processo, em especial frente aos problemas teóricos relativos ao direito de ação, é investir no radical privilégio à dimensão democrática que deve respaldar todo fenômeno processual penal. Perceber isto, desde uma nova economia dos conceitos normativos ${ }^{80}$, é pensar os poderes e deveres que emanam das normas ${ }^{81}$, e identificar o objeto do processo penal desafeto a teorias ecléticas que nada dispõem sobre sua necessária posição na jurisdição penal. A produção tradicional de um léxico fraco em matéria processual

\footnotetext{
${ }^{79}$ A pretensão processual por Guasp fundamentalmente "es, por primer término, el no ser una declaración de voluntad cualquiera, sino una declaración petitoria, una declaración en que la voluntad exteriorizada agota su sentido en la solicitud dirigida a algún otra elemento externo para la realización de un cierto contenido" GUASP, Jaime. La Pretensión Procesal. In: Estudios Jurídicos. Madrid: Civitas, 1996, p. 604. ${ }^{80}$ CORDERO, Franco. Gli Osservanti: Fenomenologia delle norme. Torino: Nino Aragno, 2008, p. 31 ss.. ${ }^{81}$ CORDERO, Franco. Guida alla procedura penale. Roma: UTET, 1986, pp. 14-17.
} 
penal não contribui para o aperfeiçoamento da disciplina e ainda menos da democracia. ${ }^{82}$ Assim, longe estaremos de um garantir antes, sim, o processo como meio jurisdicional para realizar o acertamento/comprovação do fato penal desde o poder de punir judicial, todavia que supõe mecanismos-limite de contenção ao poder punitivo.

\section{REFERÊNCIAS}

ALCALÁ-ZAMORA Y CASTILLO, Niceto. Estudios de Teoría General e Historia del Proceso (19451972). Tomos I ( $\left.n^{\circ} 1-11\right)$ e II $\left(n^{\circ} 12-30\right)$. Primera reimpresión. México: Universidad Nacional Autônoma de México, 1992.

BETTI, Emilio. Ragione e azione. Rivista de Diritto Processuale Civile, Ano X, Vol. IX, Parte I, Padova, CEDAM, 1932.

BORGES, José Afonso. Inépcia da Petição e Direito de Ação. Revista Forense, n. 138, Rio de Janeiro, 1951.

BÜLOW, Oskar von. Excepciones Procesales y Presupuestos Procesales. Traducción de Miguel Angel Rosas Lichtschein. Buenos Aires: EJEA, 1964.

BUZAID, Alfredo. Grandes Processualistas. São Paulo: Saraiva, 1982.

CALAMANDREI, Piero. La relatività del concetto di azione. Rivista de Diritto Processuale Civile, Ano XII-XIII, Vol. XVI, Parte I, Padova, CEDAM, 1939.

CALAMANDREI, Pietro. Los Estudios de Derecho Procesal en Italia. Traducción de Santiago Sentis Melendo. Buenos Aires: EJEA, 1959.

CAMARGO, Acir Bueno de. Windscheid e o rompimento da fórmula de Celso. In: Crítica à Teoria Geral do Direito Processual Penal. COUTINHO, Jacinto Nelson de Miranda (Coord.). Rio de Janeiro: Renovar, 2001.

CARNELUTTI, Francesco. Cenerentola. Rivista di Diritto Processuale, Num. 3-4 - P. I, Padova, CEDAM, 1946.

82 “(...) gli ordinamenti evoluti impongono una riserva giurisdizionale; «nulla poena sine iudicio». Quest'ultimo è l'operazione riflessiva con cui l'investito del potere di punire accerta se debba condannare o assolvere". Adiante resumindo em conclusão: "i giudici hanno il monopolio degli strumenti penali; se qualcuno debba essere punito e come, lo dicono norme legislative. Il processo è un 'operazione riflessiva: uno o più giudice stabiliscono se, nel caso de quo, esista quel dovere (vecchie formule evocavano un 'diritto di punire' o 'pretesa punitiva', assimilando il fenomeno penalistico al credito). Notiamo come potere e dovere siano figure independenti: il giudice deve condannare solo chi risulti colpevole, ma l'atto (non riformato o annullato) varrebbe anche se esorbitasse dal limite; l'unico rimedio sta nei mecanismi correttivi endoprocessuali. Siano tutti esposti al potere di punire, colpevoli $e$ no." (CORDERO, Franco. Procedura Penale. 7. ed.. Milano: Giuffrè, 2003, pp. 10 e 13-14). 
CARNELUTTI, Francesco. Lições sobre O Processo Penal. Volume 2. Traduzido por Francisco José Galvão Bruno. Campinas: Bookseller, 2004.

CHIOVENDA, Giuseppe. Instituições de Direito Processual Civil. Volume I (As relações processuais, A relação processual ordinária de cognição). Tradução da 2. ed. italiana por J. Guimarães Menegale, acompanhada de notas pelo Prof. Enrico Túlio Liebman. $3^{\mathrm{a}}$ ed. com introdução do Prof. Alfredo Buzaid. São Paulo: Saraiva, 1969.

CONSO, Giovanni. Istituizioni di Diritto e Procedura Penale. Milano: Giuffrè, 1964.

CORDERO, Franco. Gli Osservanti: Fenomenologia delle norme. Torino: Nino Aragno, 2008.

CORDERO, Franco. Guida alla procedura penale. Roma: UTET, 1986.

CORDERO, Franco. Procedura Penale. Settima edizione. Milano: Giuffrè, 2003.

COUTINHO, Jacinto Nelson de Miranda. A lide e o conteúdo do processo penal. Curitiba: Juruá, 1989.

COUTINHO, Jacinto Nelson de Miranda. Efetividade do processo penal e golpe de cena: um problema às reformas processuais. In: Escritos de Direito e Processo Penal em homenagem ao professor Paulo Cláudio Tovo. WUNDERLICH, Alexandre. Rio de Janeiro: Lumen Juris, 2002.

COUTURE, Eduardo J.. Fundamentos do Direito Processual Civil. Tradução do Dr. Rubens Gomes de Souza. São Paulo: Saraiva, 1946.

COUTURE, Eduardo. Fundamentos del Derecho Procesal Civil. 4. ed. Montevideo: Be de F, 2005.

DIAS, Jorge de Figueiredo. Direito Processual Penal. Clássicos Jurídicos. (1. ed. 1974). Reimpressão. Coimbra: Coimbra, 2004.

FAIRÉN GUILLÉN, Victor. Estudios de Derecho Procesal. Madrid: ERDP, 1964.

GOLDSCHMIDT, James. Derecho Justicial Material. Buenos Aires: EJEA, 1959.

GOLDSCHMIDT, James. Problemas Jurídicos y Políticos del Proceso Penal: Conferencias dadas en la Universidad de Madrid en los meses de diciembre de 1934 y de enero, febrero y marzo de 1935. Barcelona: Bosch, 1935.

GOLDSCHMIDT, Roberto. Derecho Justicial Material Civil. Buenos Aires: EJEA, 1959.

GÓMEZ ORBANEJA, Emilio; HERCE QUEMADA, Vicente. Derecho Procesal Penal. 10. ed. Madrid: Artes Gráficas y Ediciones S. A., 1987.

GUARNERI, Jose. Las Influencias del Derecho Civil en el Derecho Penal (Ensayo sobre alguns conceptos de la parte general de Derecho Penal). Traducción del Dr. Constancio Bernaldo de Quiros. Puebla: Publicaciones de la Universidad de Puebla, s/d.. 
GUASP, Jaime. La Pretensión Procesal. In: Estudios Jurídicos. ARAGONESES ALONSO, Pedro (coord.). Madrid: Civitas, 1996.

JARDIM, Afrânio Silva. Direito Processual Penal. 11 ed. Rio de Janeiro: Forense, 2005.

KUHLMANN, Sylvio Roberto Degasperi. A actio sob a ótica de Muther, a partir da definição de Celso. In: Crítica à Teoria Geral do Direito Processual Penal. COUTINHO, Jacinto Nelson de Miranda (Coord.). Rio de Janeiro: Renovar, 2001.

LACERDA, Galeno. Ensaio de uma Teoria Eclética da Ação. Revista da Faculdade de Direito de Porto Alegre. Porto Alegre, 1958.

LACERDA, Galeno. O Despacho Saneador. 2. ed. Porto Alegre: SAFE, 1985.

LEAL, Rosemiro Pereira. Teoria Geral do Processo. 7 ed. Rio de Janeiro: Forense, 2008.

LIEBMAN, Enrico Tullio. L'Azione Nella Teoria del Processo Civile. Problemi del Processo Civile. Napoli: Morano Editore, 1962.

LIEBMAN, Enrico Tulio. Manuale di Diritto Processuale Civile I. Milano: Giuffrè, 1984.

LIEBMAN, Enrico Tullio. Manual de Direito Processual Civil. v I. 3. ed. São Paulo: Malheiros, 2005.

LOPES JR., Aury. Direito Processual Penal e sua Conformidade Constitucional. Volume I. 5. ed.. Rio de Janeiro: Lumen Juris, 2010.

MANZINI, Vincenzo. Tratado de Derecho Procesal Penal. t I. Buenos Aires: El Foro, 1996.

MARQUES, José Frederico. Elementos de Direito Processual Penal. Volume I. São Paulo:

Forense, 1961.

MARQUES, José Frederico. Instituições de Direito Processual Civil. V. II. 3 ed. Rio de Janeiro: Forense, 1966.

MAZZARELLA, Ferdinando. Prefazione. Soliloqui e Colloqui di un Giurista. SATTA, Salvatore. Nuoro: Ilisso, 2004.

MESQUITA, Botelho de. Da Ação Civil. São Paulo: Revista dos Tribunais, 1975.

MIRANDA, Pontes de. Comentários ao Código de Processo Civil. Rio de Janeiro: Forense, 1973.

MONACCIANI, Luigi. Azione e Legitimazione. Milano: Giuffrè, 1951.

MOREIRA, J. C. Barbosa. Legitimação Para Agir. Indeferimento da Petição Inicial. Temas de Direito Processual. São Paulo: Saraiva, 1994.

MORENO CATENA, Victor; CORTÉS DOMINGUEZ, Valentín; GIMENO SENDRA, Vicente. Introducción al Derecho Procesal. 3. ed. Madrid: Colex, 2000. 
PASSOS, José Joaquim Calmon de. A Ação no Direito Processual Civil Brasileiro. Salvador: Oficinas Gráficas da Imprensa Oficial da Bahia, 1960.

PEKELIS, Alessandro. Azione. Nuovo Digesto Italiano. v II. torino: UTET, 1938.

PODETTI, José Ramiro. Teoría y técnica del proceso civil y trilogía estructural de la ciencia del proceso civil. Buenos Aires: Ediar, 1963.

PODETTI, José Ramiro. Trilogia estructural de la ciencia del proceso. Revista de Derecho Procesal. Año II. 1ª Parte. Buenos Aires: Ediar, 1944.

PUGLIESE, Giovanni. Introducción. In: Polémica sobre la Actio. WINDSCHEID, Bernhard; MUTHER, Theodor. Traducción del alemán por Tomás A. Banzhaf. Buenos Aires: EJEA, 1977.

ROCCO, Arturo. Cinco Estudios sobre Derecho Penal. Traducción de Bernardo Nespral et.al. . Montevideo-Buenos Aires: B de f-Euros, 2003.

SATTA, Salvatore. Soliloqui e Colloqui di un Giurista. Prefazione di Fernando Mazzarella. Nuoro: Ilisso, 2004.

SERRA DOMÍNGUEZ, Manuel. Jurisdicción, acción y proceso. Barcelona: Atelier, 2008.

SILVA, Ovídio. Ação de Imissão na Posse. 3. ed. São Paulo: Revista dos Tribunais, 2001.

SILVA, Ovídio Baptista da. Curso de Processo Civil. v. I. 2. ed. Porto Alegre: SAFE, 1991

SILVA, Ovídio Baptista da; GOMES, Fábio Luiz. Teoria Geral do Processo. 4 ed. São Paulo: Revista dos Tribunais, 2006.

THON, August. Norma Giuridica e Diritto Soggetivo: indagini di teoria generale del diritto. 2 . ed. Padova, 1951.

TUCCI, Rogério Lauria. Teoria do Direito Processual Penal: jurisdição, ação e processo penal (estudo sistemático). São Paulo: RT, 2002.

WACH, Adolf. Manual de Derecho Procesal Civil. Buenos Aires, Ediciones Jurídicas EuropaAmérica, 1977.

\section{COMO FAZER A REFERÊNCIA DO ARTIGO (ABNT):}

AMARAL, Augusto Jobim do; Gloeckner, Ricardo Jacobsen. Direito de Ação no Processo Penal: polêmicas e horizontes possíveis. Revista Eletrônica do Curso de Direito da UFSM, Santa Maria, RS, v. 13, n. 3, p. 1016-1042, dez. 2018. ISSN 1981-3694. Disponível em: < https://periodicos.ufsm.br/revistadireito/article/view/30765 >. Acesso em: dia mês. ano. doi: http://dx.doi.org/10.5902/1981369430765 . 